\title{
The Drug Efficacy and Adverse Reactions in a Mouse Model of Oral Squamous Cell Carcinoma Treated with Oxaliplatin at Different Time Points During a Day [Corrigendum]
}

\author{
Yang K, Zhao N, Zhao D, Chen D, Li Y. Drug Des Devel \\ Ther. 2013;7:511-517.
}

The authors apologize for this error and advise it does not affect the results of the paper.

The authors have advised due to an error at the time of figure assembly, Figure 1 on page 514 is incorrect. The correct Figure 1 is shown below.

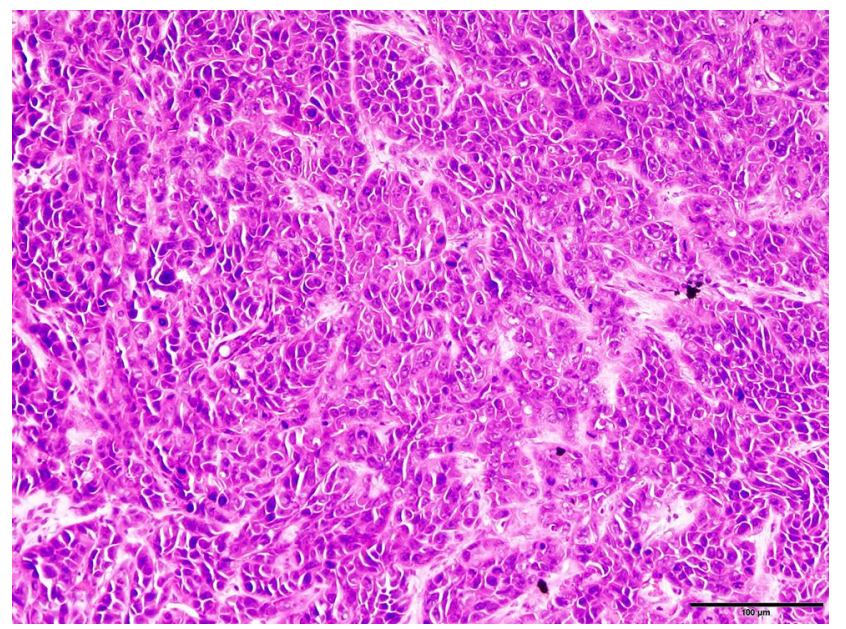

Figure I Pathological section of tumor formed 3 weeks after the inoculation of Tca8II3 cells into the cheek of nude mice (hematoxylin and eosin stain, $\times 200$ ).

\section{Publish your work in this journal}

Drug Design, Development and Therapy is an international, peerreviewed open-access journal that spans the spectrum of drug design and development through to clinical applications. Clinical outcomes, patient safety, and programs for the development and effective, safe, and sustained use of medicines are a feature of the journal, which has also been accepted for indexing on PubMed Central. The manuscript management system is completely online and includes a very quick and fair peer-review system, which is all easy to use. Visit http://www. dovepress.com/testimonials.php to read real quotes from published authors. 